\title{
昚給食の栄養管理に関する考察（第 1 報） \\ Studies on the Nutritional Administration of Mass Feeding in Dormitory (Report 1)
}

\author{
統一食費を中心とした栄養摂取状況について \\ Situation of the Nutritional Feeding in the Limitative Same Cost
}

四天王寺女子短期大学 (Shitennoji Women’s Junior College)

森田みす急 (Misue Morita)

The management of mass feeding has various difficult problems according to the purpose and character provided.

The feeding in the dormitory, one of the industrial mass feedings, is not the same in nutritional administration.

This research and investigation was made on the nutritional administration (in the limitative same cost) in seven bachelor dormitories in which had been provided meals by experienced cook without a dietetian.

The summary of the same as follows:

1) In the dormitory, where had been provided more than 100 meals, the conditions of nutritive intake was fairly well.

2) In the dormitory which had many employees in proportion to the meals provided in small quantity, the nutritive intake was low.

3) As for the food composition, animal foods intake shows a tendency to increase according to the increase in feeding number. Cereals, especially rice intake was high in the dormitory where had been provided meals in small quantity.

In due consideration of the above, in small scale feeding establishments, the nutritional administration must be improved especially on the menu making and the use of the food cost.

\footnotetext{
緒 言

現在わが国て行なわれている集団給食の大きなものに, 職域（産業）給食, 病院給食, 学校給食の 3 種があ る。これら 3 大集団給食には，それぞれの性格および相違点がみられる1)。そのなかの職域（産業）給食の 1 つてある寮給食についても，その栄養管理は一様てない。すなわち，給食の法的規定のないこと（したがって 給与基準の法定がない)，給食材料費および食費の限界がない（大部分が喫食者負担て金額の限界も任意であ
} 
る), 給食の様式が直営から次第に委託増加の傾向にあること, 食事回数が施設により一定てない点 $(1,2$, 3 回およびそれ以上の場合もある)，また食数の均等性を欠いている点および単一献立の多いことなど，他の 2 大集団給食に比し給食目的の相違にともなって, 運営, 管理においても種々の問題点ならびに困難性が考え られる。

このような現状にある寮給食の栄養管理について, 大阪府下 $\mathrm{D}$ 銀行の行員寮 7 施設 688 名を対象として, と くに統一食費のなかて各施設において，それぞれの献立が作成されているが，どのように栄養効率高く消費さ れているかに中心をおいた。すなわち，栄湌士もおらず経験的に給食が行なわれている点から，実質的に基準 量に対し献立量はどの程度給与されているかの問題を, 給食数や給食従事員などとの関連について現状の観察 調査を行なった。ここにその結果の概要を報告する。

\section{調 查 対 象}

昭和 43 年 7 月初旬のうち, とくに土, 日曜日および給料日以後の 7 日間を除き, 外泊, 外食などの比較的少 ない任意の連続 3 日間をえらんだ。

給食は $\mathrm{D}$ 銀行直営て，各行員䄅の独身男子寮生総数 688 名を刘象とした。その内訳は給食数が 1 回 50 食以上 100 食まてのものが 5 施設, 100 食以上 200 食までが 2 施設であった。平均年令は $22.7 才$, 平坞学作強度は行内 事務の非常に軽い程度のものてあった。また給食献立は各寮別に作成された単一献立による 2 食給食 (朝, 夕) である地域的差異については，7施設ともにいずれも大阪市周辺の都市にあり，地域的条件その他について 著しい格差はみられない。

\section{調查方 法}

各寮別の実施献立表から捸取栄養量, 基準量を算出し, 給食数, 給食費, 給食従事員数を把握して, 給食費 を中心に熱量, 蛋白質などの栄養摂取状況, 摂取効率その他統一食費による各寮の栄養管理の実態について考 察を行なった。

なお 1 日 2 食当たり栄養基準量の算定基礎として, 対象者の労働強度が平均的に非常に軽い労作と判定し, 日本人の栄養所要量（昭和 45 年 $)^{2)}$ よりその数値を用い，また栄養価算定には三訂日本食品標準成分表 ${ }^{32}$ を使 用した。

栄養配率については, 一般に適応されている主食, 朝, 昼, 夕を $1: 1: 1$, 副食 $1: 1.5: 1.5$ (山田慎三案4) のうち，主食配率は各寮の朝，夕の主食攝取量を算出した結果，その配率が上述の配率に近い数値をえたが， 副食の昼食配率が対象者の労作強度および昼食が配置された職場で, それぞれの自由喫食などの点から夕食と 同率の摂取は困難てはないかと考えられ，その想定にもとつ゚いて寮別献立表から使用食品，数量および捸取栄 養量などを検討した結果， $1: 1: 2$ の配率が適当と考えられる。したがって熱量，蛋白質および脂質について は,この算定基礎にもとづいて基準量をもとめた。

すなわち, 熱量について栄養摂取状況からみて, 総熱量に対する主食熱量比がおよそ60\%を占めていること から, 労作別栄養所要量 $2280 \mathrm{Cal} \times 0.6=1368 \mathrm{Cal}$ をむとめ, 1 食当たり主食量ならびに熱量を主食配率 $1: 1$ : 1 にしたがって $455 \mathrm{Cal}$ を算出した。また副食からえられる熱量 $(2280 \mathrm{Cal}-1368 \mathrm{Cal}=912 \mathrm{Cal})$ を配率にし たがって算出し $1594 \mathrm{Cal}$ の熱量基準量がえられた。 
主食 $1: 1: 1$

Cal $455: 455: 455=1365$ Cal

副食 $1: 1: 2$

計 $2277 \mathrm{Cal} 2$ 食当たり (朝, 夕) $=683: 911=1594 \mathrm{Cal}$

Cal 228:228:456=912 Cal

動物性蛋白質の基準量算定基礎として, 各尞の栄蚨摂取状況から判定し, 総蛋白質の40\%て算出した。

また無機質およびビタミン類の微量栄養素が, 主食からの期待がわずかである点を考慮にいれ, 朝, 夕副食 の栄養配率にしたがって栄養所要量（昭和 45 年, 労作別を考虑）の $3 / 4$ を算定基礎として算出した。

\section{成績および考察}

1) 給 食費

恭生の給食は朝, 夕 2 食給食であり, 昼食はそれぞれ配置された銀行において自由喫食がなされている。し たがって寮給食費は 1 人 1 日当たり 2 食平均 158 円で統一され，そのうち朝食平均 58 円，夕食平均 100 円て 1 力月平均給食費が 4,750 円でり, 各寮 7 施設とも統一食費てあった。このように統一された食費の枠内で献 立は各寮別に作成されている現状である。

2) 栄養摂取量

寮別 1 人 2 食平均栄養摂取量は表 1 に示すとおりで, 統一された食費とそれぞれの給食数からみて, 給食数 の少ない施設ほど摂取量は低く基準量を下回っている。しかしビタミン $\mathrm{B}_{1}$ については寮 $\mathrm{V}$ が強化米を常用し て扣り，1 人当たりビタミン $\mathrm{B}_{1}$ 摂取量は著明て $1.54 \mathrm{mg}$ を示しビタミン $\mathrm{B}_{1}$ 強化について栄養的配慮がうか がえる。

表 1 寮別 1 人 2 食当たり栄養掑取量

\begin{tabular}{|c|c|c|c|c|c|c|c|c|c|c|}
\hline \multirow{2}{*}{ 智 } & \multirow{2}{*}{ 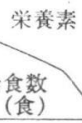 } & \multirow{2}{*}{$\begin{array}{c}\text { 熱 量 } \\
(\mathrm{Cal})\end{array}$} & \multirow{2}{*}{$\begin{array}{c}\text { 蛋白質 } \\
\text { ( } \mathrm{g} \text { ) }\end{array}$} & \multirow{2}{*}{$\begin{array}{c}\text { 動物性 } \\
\text { 蛋白贔 } \\
\text { ( }) \text { (a) }\end{array}$} & \multirow{2}{*}{$\begin{array}{c}\text { 脂 質 } \\
(\mathrm{g})\end{array}$} & \multirow{2}{*}{$\begin{array}{l}\text { カルシ } \\
\text { ウム } \\
(\mathrm{mg})\end{array}$} & \multicolumn{4}{|c|}{ ビ タミン } \\
\hline & & & & & & & A(I.U.) & $\mathrm{B}_{1}(\mathrm{mg})$ & $\mathrm{B}_{2}(\mathrm{mg})$ & $\mathrm{C}(\mathrm{mg})$ \\
\hline I & 56 & 1450 & 46.9 & 18.1 & 27.3 & 403 & 691 & 0.62 & 0.35 & 86 \\
\hline II & 76 & 1715 & 39.3 & 10.9 & 40.6 & 353 & 576 & 0.71 & 0.30 & 61 \\
\hline III & 79 & 1744 & 44.6 & 9.1 & 41.5 & 400 & 437 & 0.89 & 0.38 & 77 \\
\hline IV & 95 & 1681 & 55.2 & 20.3 & 41.7 & 425 & 909 & 0.81 & 0.69 & 49 \\
\hline V & 99 & 1593 & 52.2 & 25.3 & 38.1 & 317 & 1493 & 1.54 & 0.45 & 81 \\
\hline VI & 123 & 2032 & 75.6 & 38.1 & 47.5 & 454 & 1388 & 0.70 & 0.75 & 104 \\
\hline VII & 160 & 2063 & 82.4 & 38.9 & 36.1 & 588 & 1816 & 0.88 & 0.84 & 109 \\
\hline \multicolumn{2}{|c|}{ 栄養基準量 } & 1594 & 54.3 & 21.7 & 27.0 & 525 & 1500 & 0.83 & 0.83 & 49 \\
\hline
\end{tabular}

3) 給食数との関係

統一された給食費に対して，7施設の栄養摂取の内容がそれぞれ異なる実態をえたが，さらに給食費 1 円当 たりの熱量打よび蛋白質をはじめ, 各栄養素についての摂取状況が給食数と何らかの関係をもつものと考えら れるのでこれらの考察を行なった。(図1，2，3）

給食費 1 円当たりの熱量および蛋白質, 動物性蛋白質の摂取量は, 給食数が大となるにしたがい増大する傾

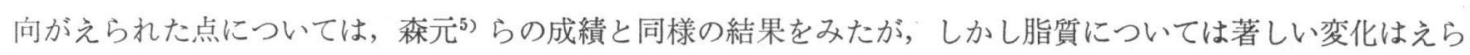
れなかった。また無機質の摂取では, カルシウムは 100 食以上の施設では増大を示しているが，100 食未満で 
図 1 給食数と給食費当たり Cal, 蛋白質, 脂質摂取状況

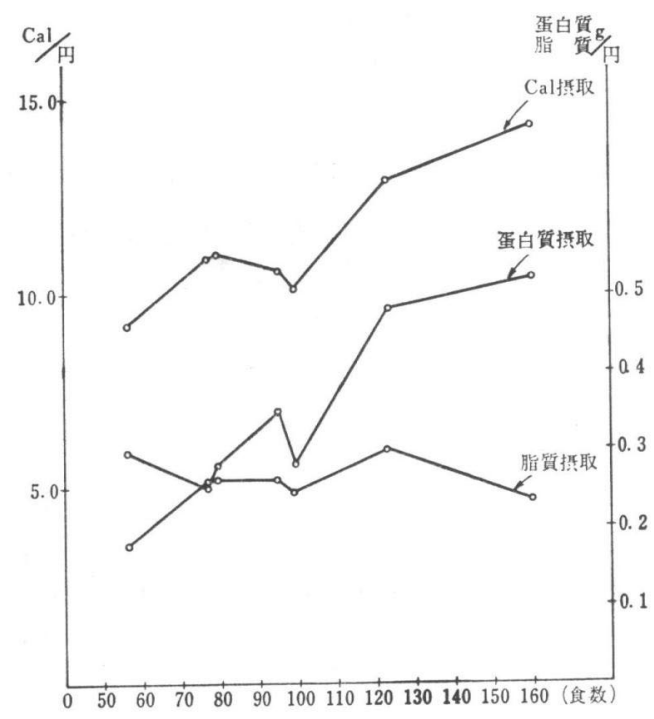

図 3 給食数と給食費当たり Ca および ビタミン $\mathrm{A}, \mathrm{B}_{1}, \mathrm{~B}_{2}, \mathrm{C}$ 摂取状況

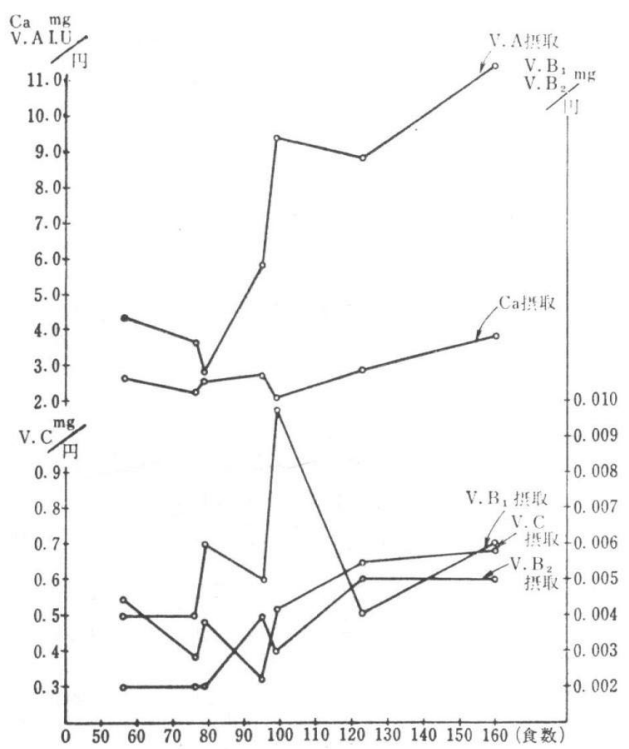

図 2 給食数と給食費当たり動物性蛋白質, 鉄摄取状況

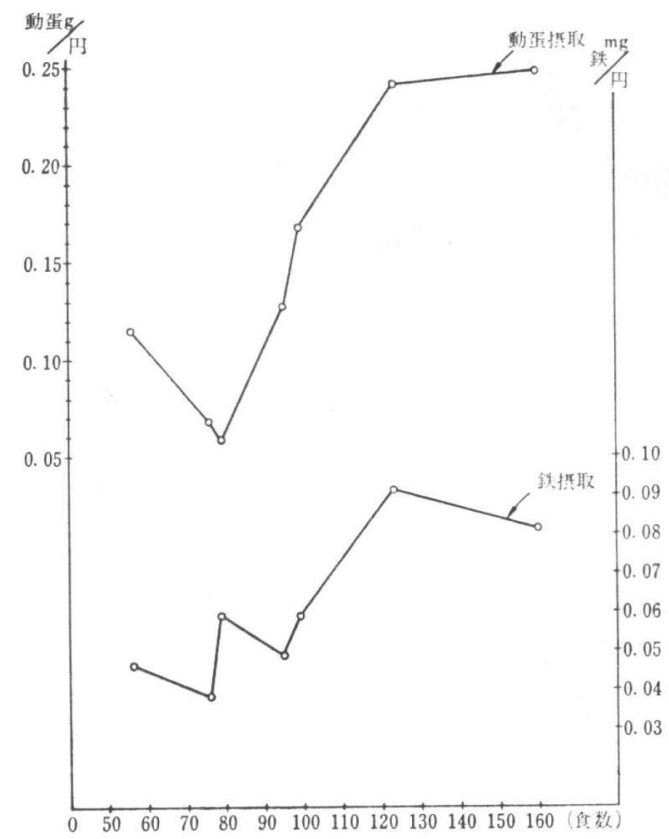

は脂質と同様著しい変化はみられなかった。鉄の摂取ては 寮林が最高て給食費当たり 0.091mg を示しているが，食 数増加にしたがいやや低下している。またビタミン類は強 化米使用の寮 $\mathrm{V}$ を除いて, 給食数の増加にともない增大す る傾向をみた。

以上のことから 70 食より 100 食の給食数の間に, いずれ も共通して多少の増減変化がみとめられる傾向について, この給食数の範囲が栄養管理において, 食品購買と材料費 の効率的運用の面て, 難かしい問題が介在するものと考え られる。また 100 食を基点として給食数の増加にしたがい 調理，加工，配膳の過程における損失が少なくなるのては ないかと考えられる。

4) 摂取効率について

統一された食費のなかて栄養基準量に対して栄養的な消費がなされているかの問題について, 各尞別の栄養 摂取状況を比較検討した。図 4 に示すとおり脂質とビタミンC C 7 施設とも基準量を満たしているが，しかし ビタミンCについては調理操作上の損失を考虑すれば, 寮 VI, VII の 2 施設を除き増量の必要がみとめられる。 また熱量は給食数の最小の寮 I を除いては基準量をみたしているが, 蛋白質は寮 IV, VI, VII 除き他の施設て は基準量に達しておらず，いずれも食数 100 食末満の施設であった。動物性蛋白質の摂取量も基準量に対しや はり 100 食未満の施設は下回っている。またカルシウムおよびビタミン $\mathrm{A}, \mathrm{B}_{1}, \mathrm{~B}_{2}$ においても給食数最大の 寮VIIが基準量よりも多く摂取している。 
すなわち，統一された 食費に対し熱量や蛋白質 その他の栄養素を比較的 十分に摂取している施設 は, 給食数 100 食以上の ところであった。つぎに 摂取効率の低值を示す寮 I , II, III の施設の給食 数と給食従事員数の関連 について, 100 食以上の 施設と比較したものが表 2 てある。攝取効率の高 い施設に対し，低值を示

しているところは比較的給食従事員数も多く，また従事員 1 名当たりの食数も少ない。このことは給食施設設 備によることも考えられるが，献立内容の栄養診断と指導の必要性が痛感される。調査対象の 7 施設が栄養士 皆無てあり，経験的給食に依存していると考えられる点が少なくない。

表 2 給 食 数と給 食従事員

\begin{tabular}{|c|c|c|c|c|c|}
\hline 区分 & 給食数 (食) & $\begin{array}{c}\text { 給食従事員 } \\
\text { (人) }\end{array}$ & $\begin{array}{l}\text { 給食従事員 } 1 \text { 名当た } \\
\text { り食数 }\end{array}$ & 栄養士有無 & 調理師有無 \\
\hline I & 56 & 6 & 9.3 & 無 & 有 \\
\hline II & 76 & 10 & 7.6 & 無 & 有 \\
\hline III & 79 & 9 & 8.7 & 無 & 有 \\
\hline IV & 95 & 8 & 11.8 & 無 & 有 \\
\hline $\mathrm{V}$ & 99 & 10 & 9.9 & 無 & 有 \\
\hline VI & 123 & 11 & 11.1 & 無 & 有 \\
\hline VII & 160 & 12 & 13.3 & 無 & 有 \\
\hline
\end{tabular}

5）食糧構成の検討

栄養摂取状況と関連して各施設別の摂取食糧構成について表 3 に示す成績をえた。すなわち総摂取量に刘し 動物性食品を多量損取しているところは，寮 IV $30.2 \%$ 占め他の施設に比べて著明てあった。その食糧構 成をみると牛乳 $18.3 \%$ て牛乳摂取はこの施設だけてあった。ついて獣鳥鯨肉類 $6.4 \%$, 卵類 $5.5 \%$ を摂取し ている。その他の施設ては尞 V, VI，VII て給食数の増大にしたがい動物性食品の摂取上昇がみられた。また魚 介類の生物の摂取も給食数の大てある施設にかぎられているが，これに対し魚介類乾物その他および獣鳥鯨肉 類は, 比較的給食数の少ない施設において摂取がみられた。乳製品の摂取は寮 $\mathrm{I}$ と Vのわずか 2 施設にすぎず また卵類も給食数の多い施設において摂取されていた。

植物性食品の摂取構成て著明な点は，寮 IV の米類摂取が他の施設に比べて低く，それに対し小麦類が $21.0 \%$ を占め, 著しい差がみられた。これは朝食にパン食利用の嗜好傾向によるものと考えられ, 喫食調査, 嗜好調 査なども行なわれており食糧構成が他の施設に比へて，かなり良好なものとみとめられる。 
表 3 寮 別食品群別摂取量比較 (\%)

\begin{tabular}{|c|c|c|c|c|c|c|c|c|}
\hline \multirow{2}{*}{\multicolumn{2}{|c|}{ 食品群別 給食数 }} & I & II & III & IV & V & VI & VII \\
\hline & & 56 & 76 & 79 & 95 & 99 & 123 & 160 \\
\hline \multirow{3}{*}{\multicolumn{2}{|c|}{$\begin{array}{llll}\text { 総 } & & & \text { 量 } \\
\text { 動 物 性 食 品 } & \text { 計 } \\
\text { 植 物 性 食 } & \text { 品 } & \text { 計 }\end{array}$}} & 100.0 & 100.0 & 100.0 & 100.0 & 100.0 & 100.0 & 100.0 \\
\hline & & 10.0 & 7.7 & 4.9 & 30.2 & 14.3 & 14.9 & 16.4 \\
\hline & & 90.0 & 92.3 & 95.1 & 69.8 & 85.7 & 85.1 & 83.6 \\
\hline \multirow{15}{*}{$\begin{array}{l}\text { 植 } \\
\text { 物 } \\
\text { 性 } \\
\text { 食 } \\
\text { 品 }\end{array}$} & \multirow{3}{*}{ 穀 $\left\{\begin{array}{lrr}\text { 米 } & \text { 類 } \\
\text { 小 } & \text { 麦 } & \text { 類 } \\
\text { その他の穀 }\end{array}\right.$} & 34.9 & 39.8 & 31.7 & 16.8 & 25.4 & 30.9 & 27.8 \\
\hline & & 2.7 & 1.9 & 3.4 & 21.0 & - & - & 3.9 \\
\hline & & - & - & - & - & - & - & - \\
\hline & 種 & - & 0.3 & - & - & - & - & 0.2 \\
\hline & w & 0.4 & 5.1 & 15.6 & - & 7.3 & 4.4 & 4.3 \\
\hline & 砂 & 1.3 & 3.0 & - & - & - & - & 0.2 \\
\hline & 菓 & - & - & - & - & - & - & - \\
\hline & 油 & 0.4 & 1.4 & 1.7 & 0.3 & 0.5 & 0.5 & 1.6 \\
\hline & 豆 /大豆及製品 & 9.6 & 3.1 & 4.8 & 5.3 & 3.5 & 9.4 & 4.7 \\
\hline & 類〔その他の豆類 & - & - & - & - & - & - & - \\
\hline & 果 & - & - & - & 1.1 & 16.0 & 1.2 & 8.5 \\
\hline & 緑 黄 色 野 菜 類 & 23.7 & 10.6 & 14.7 & 8.2 & 5.3 & 10.0 & 7.4 \\
\hline & その他の野菜及茸類 & 15.4 & 24.5 & 19.8 & 14.0 & 26.7 & 26.8 & 21.7 \\
\hline & 海 & 0.3 & - & 0.2 & - & - & 0.4 & 0.2 \\
\hline & 調味嘹好品 及 飲料 & 1.3 & 2.6 & 3.2 & 3.1 & 1.0 & 1.5 & 3.1 \\
\hline \multirow{6}{*}{$\begin{array}{l}\text { 動 } \\
\text { 物 } \\
\text { 性 } \\
\text { 食 } \\
\text { 品 }\end{array}$} & 魚類 」生 & - & - & - & - & 1.0 & 8.1 & 7.8 \\
\hline & 介 乾物その他 & 1.3 & 1.3 & 1.1 & - & 0.3 & 0.3 & 0.8 \\
\hline & 獣 鳥 鯨 肉 類 & 8.0 & 6.4 & 3.8 & 6.4 & 6.0 & 6.4 & 7.8 \\
\hline & & - & - & - & 5.5 & 6.0 & 0.1 & - \\
\hline & 乳 生 & - & - & - & 18.3 & - & - & - \\
\hline & 類 乳 & 0.7 & - & - & - & 1.0 & - & - \\
\hline
\end{tabular}

油脂類では寮 III，VIIおよび II の摄取順位で，その他の施設ては大差はみられない。大豆および製品，緑黄色 野菜類は給食数最小の寮 I が $9.6 \% ， 23.7 \%$ とそれぞれ高率を示している。また果実類は 95 食以上の 4 施設に おいてのみ摂取していた。

食糧構成からみて給食数が少ない施設では穀類の占める割合が高く, 大豆および製品，野菜類の消費が比較 的大であり，それに対し動物性食品の摂取は総摂取量のおよそ10\%にすぎないことがわかった。

\section{結 論}

D銀行の行員寮で行なっている镣給食が，統一食費のなかて各昚別献立にしたがって実施されているが，給 食数や給食従事員との関連性がきわめて大であることが推察された。

（1）熱量や蛋白質その他の栄養椇取が良好な施設は, 給食数が 100 食以上の施設にみられいずれも基準量を满 たしていた。

（2）給食数が少数でしかも給食数に対し給食従事員の比較的多い施設において,摃取効率は低値を示していた。

(3)，食糧構成は給食数の増大にしたがい動物性食品の摂取が増加する傾向がみられ，また給食数の少ない施設 ほど穀類とくに米類の摂取が多い。 
集団給食施設で現在栄養士必置が義務づけられているのは病院および乳児院のみであるが，本調查の成績か らみて 100 食未満の小規模施設において, 統一食費の枠内で栄養所要量に基づいた献立作成ならびに食糧購買 と材料費の効率的運用など, 栄養管理の改善指導が痛感された。

終わりに本調査にご協力いただきましたD銀行人事部ならびに給食関係者の諸氏に深甚の謝意を表します。

\section{文献}

1) 高木和男：集団給食の理論と実際，第一出版（1965）

2) 日本人の栄養所要量（昭和 45 年）栄養審議会 (1963)

3) 日本栄養士会編：三訂日本食品標準成分表（1963）

4) 種子島, 加藤, 諏訪, 三石, 村上, 森田：栄湌指導, 建帛社 (1966)

5）森元，細谷：栄養と食糧, 19, 390 (1967)

（受付：昭和43年11月19日）

$\overline{\text { 抄 } \quad \text { 録 }}$

食品中のトリプトファンの栄養的利用性 The Nutritional Availability of Tryptophan in Foods. Praneet Pongpaew, K. Guggenheim: Nutritio et Dieta, 10, 297 (1968)

幼ラットの体重増加量の比較によって食品のトリ プトファンの利用度を測定した。また同時に，S Zymogenes および L. Arabinosus による測定を， 食品を蛋白分解酵素処理した場合とそうでない場合 につき，比較測定した。測定に供した食品は，乾燥 卵白, 非加熱乾燥スキムミルク, 湿熱20分処理スキ ムミルク, 湿熱40分処理スキムミルク, 非加熱〉、 ッシュミール，湿熱処理フィッシュミール，加熱大 豆粉, ゴマ粉, エジプト豆, 小麦粉, 米粉でる。 利用度はトリプトファンの化学的測定值の百分率で
表わした。上記食品のうち, 卵白, 非加熱スキムミ ルク, 加熱大豆粉, ゴマ粉のトリプトファンは利用 度が高いが，フィッシュミール，エジプト豆，加熱 スキムミルクの利用度は劣っていた。

食品のトリプトファンの微生物学的利用度は, S. Zymogenes による方が L. Arabinosus によるより も高かった。

なお, 酵素処理した後 S. Zymogenes で利用度を 測定するとラットで測定したよりも高い値を得るが， L. Arabinosus で測定すると，ラットで測定したよ りも低い値を与える。従って S. Zymogenes あるい は L. Arabinosus を用いて in vivoに打けるトリ プトファンの利用度を予測することは難しい。

（見目） 